\title{
The Influence of Debt Financing on Enterprise Performance -- Based on Empirical Research on Chinese A-share Listed Companies
}

\author{
Jing Feng ${ }^{1}$, Dan $\mathrm{Lu}^{1} \&$ Yonghong Yao ${ }^{1}$ \\ ${ }^{1}$ Guangzhou Huashang College, Guangzhou, Guangdong, China \\ Correspondence: Dan Lu, Guangzhou Huashang College, Guangzhou, Guangdong 511300, China. E-mail: \\ $1735422231 @ q q . c o m$
}

Received: December 23, 2021

Accepted: January 19, 2022

Online Published: January 25, 2022

doi:10.20849/ajsss.v7i1.983

URL: https://doi.org/10.20849/ajsss.v7i1.983

\begin{abstract}
The financing methods mainly include internal financing and external financing and different financing methods have different effects on performance. As an important part of the capital structure, the debt financing structure will not only affect the profit level of the enterprise, but also affect the external investors of the enterprise through signal transmission and then have an impact on the performance of the enterprise. Based on this background, it is particularly important to study whether debt financing can bring corresponding performance improvement to enterprises. Therefore, this paper selects Chinese A-share listed companies as the research sample and uses the panel data from 2016 to 2020 as the basis to use regression to conduct an empirical test on the impact of Chinese A-share listed companies' debt financing on corporate performance. The results show that there is a significant negative correlation between debt financing of Chinese A-share listed companies and corporate performance. Based on this empirical result, this article puts forward corresponding improvement suggestions, which will help promote the improvement of corporate performance.
\end{abstract}

Keywords: debt financing, enterprise performance, listed companies

\section{Introduction}

With the deepening of the transition economy and the rapid rise of emerging markets, the issue of corporate finance has become a bottleneck for enterprises to leapfrog into development. Among them, debt financing is both a difficult source of corporate finance drivers and a constant focus of academic attention. Corporate finance refers to a series of activities that it undertakes as the demand side of capital for the purpose of financing. Access to finance affects the mechanism of action of the flow of funds, which is the key to maintaining the normal operation of the enterprise. The day-to-day management activities of a company cannot be carried out without the support of funds and the continuous development and growth of an enterprise also needs financial support. When a company faces a shortage of free cash flow in the course of its development, the choice of financing becomes a major decision that must be considered when making strategic choices and debt financing can be considered. Debt financing has these advantages: faster financing speed; greater financing flexibility; lighter capital cost burden; financial leverage can be used; and the company's control rights can be stabilized. Existing studies have found that debt financing costs are closely related to corporate financial risks, which in turn affect corporate profitability and corporate value. The pressure of the financing environment and economic environment has made the cost of corporate financing continue to rise. How to reduce debt financing costs and thereby reduce financial risks has become a top priority for companies. Therefore, for an enterprise, choosing an appropriate financing method is of vital importance to the survival and development of the enterprise. At present, scholars at home and abroad have done a lot of research on corporate debt financing issues and performance issues, but there have been controversies about the core issue of this field-the relationship between debt financing and corporate performance and a consistent view has not yet been achieved. In response to this phenomenon, this article will study the impact of debt financing on the performance of Chinese A-share listed companies from the perspective of financing methods and provide a certain reference for corporate financing.

\section{Literature Review}

\subsection{Debt Financing Has a Positive Impact on Corporate Performance}

From the perspective of agency cost, Jensen and Meckling (1976) believed that moderate debt financing would 
produce obvious incentive effect and the increase of debt cost was less than the decrease of equity cost, so that the agency cost of the company would decrease, thus improving enterprise performance. Rose (1977) pointed out that the choice of financing means of enterprises is to send a signal to the market and there is a positive correlation between corporate value and debt-to-equity ratio. Heinkel (1982) proved the impact of debt signal transmission from the perspective of information asymmetry, that is, debt financing by enterprises can deliver good news of enterprises and enterprise value is positively correlated with debt financing level. Sarig (1988) pointed out that the existence of debt would prompt the controller to strive to improve the success rate of negotiations with suppliers, which would increase enterprise value. Isarel (1989) discussed that in the face of merger and acquisition, the agent of an enterprise will increase its debt, making the value of the company rise. Kim and Stulz (1999) discussed the positive relationship between debt financing and corporate value from the perspective of stock market price.

Zhang Weiying (1996) discussed that creditors restrict managers' behavior by expanding debt financing from the perspective of shareholder nature. Yuan Guoliang (1999) pointed out that the imperfect capital market led to the failure of the corporate governance mechanism of debt financing. Wang Hui (2003) believed that debt financing could restrain managers' rent-seeking and excessive investment by controlling enterprises' free cash flow, thus improving corporate governance to a certain extent. Yan Wei (2012) concluded through regression analysis that long-term debt has a positive impact on corporate performance and there is a positive correlation between the two. Bank debt financing method is positively correlated with corporate financial performance. Peng Yi (2014) believed that the development of bond market is conducive to the improvement of corporate performance.

\subsection{Debt Financing Has a Negative Impact on Corporate Performance}

Myers and Majluf (1984) proposed that enterprises should choose more secure internal financing first and then external financing. Titman and Wessels (1988) conducted an empirical study on 469 manufacturing enterprises and proved that with the reduction of corporate debt level, corporate profitability also increased, showing a negative correlation between the two. Berkovitch (2000) discussed the influence of debt financing on enterprise value from the perspective of the relationship between debt and manager incentive and drew a negative correlation conclusion. Goyal and Frank (2003) conducted panel data regression analysis on the financial data of listed non-financial companies in the United States and concluded that corporate debt level was negatively correlated with corporate performance. At the same time, different enterprise value measurement indicators will affect the results. If book value is taken as the measurement standard of financial performance, it is concluded that debt financing level is negatively correlated with enterprise performance. Johnson (2006) found that bank loan financing was negatively correlated with corporate performance in terms of the type of corporate debt financing structure.

Chen Xiaoyue (1995) analyzed the relationship between stock market returns and debt-to-equity ratio and concluded that they were negatively correlated. Sun Yongxiang (2001) believes that debt constraints of state-owned enterprises affect the relationship between financing structure and corporate governance. Tian Lihui (2004) pointed out that with the increase of bank loan scale, enterprise performance showed a downward trend. Deng Li (2007) found that no matter the length of bank loan, there is a negative correlation with corporate performance. $\mathrm{Li} \mathrm{Ke}$ (2011) believes that the improvement of corporate financing constraints and the reduction of financing costs will improve the business performance of enterprises and enhance their competitiveness. Song Yanping (2015) made the empirical conclusion that there is a negative correlation between corporate debt financing and corporate performance and the larger the debt scale of enterprises, the greater the financial risk of enterprises, thus leading to the decrease of the value of listed companies.

\subsection{Debt Financing Has an Inverted U-shaped Relationship With Company Performance}

Chu Chengbing (2010) pointed out that the asset-liability ratio was negatively correlated with economic performance, resulting in an "inverted U-shaped" relationship between debt-financing ratio and corporate performance. Zheng Huikai and Xie Chi (2014) believe that the relationship between debt maturity structure and enterprise value is not a simple linear one, but an inverted U-shaped one. Liu Yu and Sheng Yuhua (2018) used the unbalanced panel data of China's A-share manufacturing industry from 2010 to 2016 to prove that there is an inverted U-shaped curve relationship between the scale of corporate debt financing and business performance. Moderate debt financing can promote corporate performance, while severe excessive debt financing can hinder corporate performance.

\section{Theoretical Analysis and Research Hypothesis}

According to the financing sequencing theory proposed by Myers and Majluf (1984), enterprise financing generally follows the sequence of internal financing and external financing, considering the additional cost of 
external financing due to information asymmetry. And when enterprises choose debt financing, it is to send a bad signal to the outside that the enterprise is short of funds and limited development. According to the signal transmission theory and stakeholder theory, this weakens the confidence of external investors, thus reducing the enterprise to get more investment, which is not conducive to the improvement of enterprise performance.

For example, the financing cost of bank loans is high and enterprises need to pay high interest when they repay the principal, which increases the financial risk of enterprises. Moreover, when enterprises fall into financial difficulties, they may go bankrupt because they cannot repay the principal and interest on time. At the same time, there are many restrictions on bank loans, which limit the use and amount of enterprise loans and affect the free operation decisions of enterprises. All these are not conducive to the improvement of enterprise performance.

The cost of short-term borrowing is low but the term of use is short. Excessive short-term borrowing cannot meet the capital needs of long-term investment projects of growing enterprises. In addition, as the maturity of short-term loans is near, it is easy to fail to repay the principal on time on the maturity date, or even break the capital chain, which increases the liquidity risk cost and seriously affects the performance of enterprises. And long-term borrowing cost is high, principal and interest repayment pressure is big. In addition, due to the long repayment period, decision-makers are more likely to make mistakes in judgment when enterprises make decisions, thus affecting enterprise performance.

Therefore, this paper argues that with the further expansion of the scale of enterprises, enterprises demand more and more funds. Debt financing increases the financial cost and financial risk of enterprises. Thus, the hypothesis is proposed:

H1: Debt financing has a negative impact on corporate performance, that is, the increase of debt financing scale is not conducive to the improvement of corporate performance.

\section{Research and Design}

\subsection{Sample Selection and Data Sources}

In this paper, the data of Chinese A-share listed companies from 2016 to 2020 are selected as the research samples. In order to make the samples more representative, the samples are sorted out as follows: (1) As b-share and $\mathrm{H}$-share listed companies are facing dual regulatory environment both at home and abroad, there are certain differences from other listed companies, so such listed companies are excluded; (2) Remove ST and *ST sample companies; (3) Eliminate the listed companies with missing data. After data elimination, a total of 13,841 sample observation values were finally obtained. All data in this paper were obtained from the CSMAR database and processed by Excel2016 and Stata15.0 statistical software.

\subsection{Variable Selection and Definition}

\subsubsection{Explained Variable}

According to the existing literature, corporate performance is usually measured by return on total assets (ROA), return on equity (ROE) and Tobin's Q. In this paper, return on total assets (ROA) is mainly used as the ratio of enterprise net profit to total assets, which reflects the contribution of all enterprise resources to operating results and reflects the effect of comprehensive utilization of enterprise assets.

\subsubsection{Explanatory Variables}

The main source of debt financing for Listed companies in China is bank borrowing. This paper chooses DEBT ratio to measure debt financing cost (DEBT), which is calculated as (long-term borrowing + short-term borrowing)/total assets. The higher the total loan ratio is, the higher the debt is. Therefore, the greater the cost of debt financing.

\subsubsection{Control Variables}

The selection of control variables should try to consider other important factors influencing enterprise performance except debt, so as to make the empirical results more accurate. The following control variables are selected in this paper: net cash flow per share (DCF). Net cash flow per share in an enterprise can meet the funds needed for production expansion and play a decisive role in enterprise performance. Operating profit growth rate. The level of operating profit rate reflects the strength of enterprise profitability. The higher the operating profit rate is, the more the operating profit provided by the sales of goods, the stronger the profitability of the enterprise. The lower the operating profit rate, the weaker the profitability of the enterprise, the greater the operational risk.

The specific definitions of the above variables are shown in Table 1: 
Table 1. Variable definition

\begin{tabular}{cccc}
\hline Variable type & Variable name & $\begin{array}{c}\text { Variable } \\
\text { symbol }\end{array}$ & Variable description \\
\hline $\begin{array}{c}\text { Explained } \\
\text { variable }\end{array}$ & Return on total assets & ROA & net profit/Total assets \\
$\begin{array}{c}\text { Explanatory } \\
\text { variables } \\
\text { Control } \\
\text { variable }\end{array}$ & Debt financing cost & DEBT & $\begin{array}{c}\text { (long-term borrowing }+ \text { short-term } \\
\text { borrowing)/total assets } \\
\text { net cash flow/total assets }\end{array}$ \\
& $\begin{array}{c}\text { Operating profit growth } \\
\text { rate }\end{array}$ & $\mathrm{R}$ & $\begin{array}{c}\text { current year's operating profit } \\
\text { growth/last year's total operating } \\
\text { profit }\end{array}$ \\
\hline
\end{tabular}

\subsection{Model Construction}

In order to test hypothesis 1 , the relationship between debt financing cost and enterprise performance is modeled (1):

$$
\mathrm{ROA}=\alpha_{0}+\alpha_{1} \text { DEBT }+\alpha_{2} \text { DCF }+\alpha_{3} \mathrm{R}+\varepsilon
$$

Among them, $\alpha 0, \beta 0$ are constant terms, $\alpha \mathrm{i}, \beta \mathrm{i}(\mathrm{i}=1,2,3,4,5,6)$ are coefficients and $\varepsilon$ is a random error term.

The explained variable is ROA to measure the enterprise performance and the explanatory variable DEBT is the debt financing cost of the enterprise.

If the DEBT coefficient is negative, it proves the negative correlation between the two, that is, the higher debt financing cost of enterprises is not conducive to the improvement of performance.

\subsection{Empirical Research}

\subsubsection{Descriptive Statistics}

The descriptive statistical results are shown in Table 2. The average return on total assets of China's A-share listed companies is 0.028 and the standard deviation is 0.159 , indicating that the overall corporate performance of China's A-share listed companies is good and the development is more balanced. The standard deviation of corporate debt financing cost is 0.262 and the average is 0.4347 . The standard deviation is smaller than the average, indicating that the debt financing cost data of A-share listed companies are relatively concentrated. Relatively few enterprises choose debt financing and many enterprises choose other financing methods. The standard deviation of the growth rate of enterprise operating profit is large, indicating that the operating profit of different enterprises varies greatly.

Table 2. Descriptive statistics

\begin{tabular}{ccccc}
\hline variable & Average & $\begin{array}{c}\text { Standard } \\
\text { deviation }\end{array}$ & Min & Max \\
\hline ROA & 0.028 & 0.159 & -6.437 & 0.346 \\
DEBT & 0.437 & 0.262 & 0.010 & 7.028 \\
DCF & 0.202 & 1.156 & -6.872 & 17.825 \\
R & -0.994 & 34.799 & -1039.119 & 845.928 \\
\hline
\end{tabular}

\subsubsection{Correlation Analysis}

According to Table 3, it can be seen that there is a significant negative correlation between debt financing costs and corporate performance. Only by effectively solving financing difficulties can companies promote performance improvement, which preliminarily proves that debt financing and corporate performance are negatively correlated. In addition, the cost of debt financing in the sample is highly correlated with corporate performance. Funds are the key to maintaining normal business operations and debt financing is one of the important ways to expand funding sources. However, it did not exceed the critical value of 0.7 , so the next step 
of research can be carried out. The correlation of other variables in the sample is small, indicating that there is basically no multicollinearity and the model can be regressed as a whole.

Table 3. Correlation analysis

\begin{tabular}{ccccc}
\hline & ROA & DEBT & DCF & R \\
\hline ROA & 1.000 & & & \\
DEBT & $-0.685^{* * *}$ & 1.000 & & \\
DCF & $0.043^{* * *}$ & $-0.015^{*}$ & 1.000 & 1.000 \\
R & $0.035^{* * *}$ & -0.005 & 0.007 & \\
\hline
\end{tabular}

Note: $* * *, * *$ and $*$ are significant at $1 \%, 5 \%$ and $10 \%$ respectively.

\subsubsection{Hausmann Test}

In order to ensure the robustness of the regression results, a Hausman test was first performed on the panel data model. The results are shown in Table 4 and the $\mathrm{P}$ value is 0.000 . Therefore, this paper chooses a fixed effects model to perform regression on the panel data.

Table 4. Hausmann test

\begin{tabular}{ccccc}
\hline & $(\mathbf{b})$ & $(\mathbf{B})$ & $(\mathbf{b}-\mathbf{B})$ & Sqrt(diag(V_b-V_B $))$ \\
& FE & RE & Difference & S.E. \\
\hline DEBT & -0.846 & -0.617 & -0.229 & 0.005 \\
DCF & -0.002 & 0.007 & -0.009 & 0.001 \\
R & 0.000 & 0.000 & -0.000 & 0.000 \\
\hline
\end{tabular}

\subsubsection{Regression Analysis}

The regression results are shown in Table 5. The non-standard coefficient of DEBT is -0.617 , which is significant at the $1 \%$ level. The regression results prove the hypothesis 1 of this article, that is, there is a significant negative correlation between corporate debt financing costs and performance. Companies facing higher debt financing costs will generate higher financial risks and corporate operational risks, which is not conducive to the steady improvement of performance. Therefore, under the same conditions, companies facing lower debt financing costs will have higher corporate performance and reasonable reduction of debt financing costs will improve performance.

Table 5. Regression analysis

\begin{tabular}{ccc}
\hline Variable & Non-standardized coefficient & Sig \\
\hline DEBT & $-0.617^{* * * *}$ & 0.000 \\
DCF & $0.007^{* * * *}$ & 0.000 \\
R & $0.000^{* * *}$ & 0.000 \\
\hline
\end{tabular}

Note: $* * * * *$ and $*$ are significant at $1 \%, 5 \%$ and $10 \%$ respectively.

\subsubsection{Robustness Test}

In this paper, the quantiles below $1 \%$ and above $99 \%$ of continuous variables are narrowed down, the robustness test is carried out and the fixed-effects model is used for regression analysis. The non-standard coefficient of DEBT is -0.606 , which is significant at the level of $1 \%$. The regression results prove that there is a significant negative correlation between corporate debt financing costs and performance. The high debt financing costs faced by companies are not conducive to the steady improvement of performance. After the tailing process, the regression results are basically the same as the previous ones and Hypothesis 1 has passed the robustness test. 
Table 6. Robustness test

\begin{tabular}{ccc}
\hline Variable & Non-standardized coefficient & Sig \\
\hline DEBT & $-0.606^{* * * *}$ & 0.000 \\
DCF & $0.007^{* * * *}$ & 0.000 \\
R & $0.003^{* * *}$ & 0.000 \\
\hline
\end{tabular}

Note: $* * *, * *$ and $*$ are significant at $1 \%, 5 \%$ and $10 \%$ respectively.

\section{Conclusion and Suggestion}

\subsection{Conclusion}

This article uses data from China's A-share listed companies from 2016 to 2020 to analyze the impact of debt financing on corporate performance. This paper takes 13841 selected panel data as the research object. After theoretical and empirical research, it is concluded that debt financing has a negative impact on corporate performance, that is, the increase in debt financing is not conducive to the improvement of corporate performance. When corporate debt financing is high, on the one hand it sends a signal of limited corporate financing, which reduces the investment confidence of external stakeholders and increases creditors' risk assessment of the company, leading to higher financial and operating costs. On the other hand, it will increase the risk appetite of managers and adopt more radical management and operation methods, which may cause damage to corporate performance. Therefore, companies need to use debt financing carefully to promote corporate performance growth.

\subsection{Suggestion}

\subsubsection{Reasonable Use of Debt Financing}

Debt financing can have a positive impact on business performance, but it can also have a large negative impact. The use of debt financing increases a company's payment risk. Debt financing must ensure that the return on investment is higher than the cost of capital, otherwise it will not cover its expenses and may even lead to losses. In addition, the use of debt financing will also increase the operating costs of enterprises and affect the turnover of funds. The interest on debt financing increases the operating costs of the enterprise. Excessive use of debt financing can reduce the enterprise's refinancing ability and even endanger the enterprise's viability. Once an enterprise has excessive debt, the financing risk will increase dramatically and any problems in the operation of the enterprise will lead to debt settlement or even bankruptcy. Therefore, enterprises should use debt financing wisely according to their actual situation.

\subsubsection{Broaden Financing Channels}

More financing options means more financing opportunities available to the business. Broadening financing channels not only balances the capital structure of a company, but also reduces financial risk. China's A-share listed companies can quickly gather a large amount of capital through the stock market to invest in enterprises, stabilize or even expand their operations, which cannot be achieved by debt financing. On the one hand, companies take all means to actively go public; on the other hand, the government lowers the listing requirements on the basis of ensuring market stability in order to guide companies to take measures to expand the scale of equity financing.

\subsubsection{Strengthen the Construction of Banking Supervision Functions}

Improve the level of supervision of the banking sector in corporate debt financing and enhance the efficiency of corporate capital use through external supervision. Effective external supervision by lending banks can reduce the cost of corporate agents. Enterprises can reduce their debt financing costs by improving the internal and external financing environment, which in turn can solve the problem of difficult financing for performance improvement. However, in terms of the structure of debt financing sources, enterprises should not rely too much on banks and should strive to establish a good banking relationship, comply with lending contracts, improve bank credit and maintain their own image, so that they can obtain a higher loan amount and a lower loan ratio.

\subsubsection{Keep a Close Eye on Changes in Economic Policy}

In the current context of the need for timely adjustment of economic policies at all levels of government in China to achieve smooth economic transformation, firstly, enterprises should always pay attention to various trends in government policies and establish good relationships with the government, so as to strive to make accurate 
predictions in advance of changes in economic policy adjustments, choose appropriate financing methods and reduce the adverse consequences of miscalculations. Secondly, when formulating relevant policies, the government should consider the impact of relevant policy changes on enterprises. It should also provide enterprises with certain preferential financing policies to provide external support to reduce debt financing costs. Finally, enterprises should take advantage of the upward trend in China's economy to grow and develop, so that they can cope with changes in the external environment.

\section{Acknowledgments}

2019 Guangzhou Huashang University Academic Project "Application of Enterprise Performance Evaluation Based on Multiple Regression Analysis Model" (NO.2018HSXS05)

On-campus tutor system project of Guangzhou Huashang College "Research on the Impact of Innovation Investment in Guangdong Province on Enterprise Performance-Based on the Moderating Effect of External Financing" (NO.2020HSDS05)

Guangzhou Huashang University Key Discipline "Financial Management" Huashang College 2020[114]2020HSXK02

Guangdong Province 2021-2022 Accounting Research Project (Guangdong Provincial Department of Finance and Economics) "Research on the Impact of Government Subsidies on the Performance of Guangdong Pharmaceutical Enterprises-Based on the Intermediary Effect of R\&D Investment" (NO.8-27)

\section{References}

Bennedsen, M., Nielsen, K. M., Francisco, P. G., et al.. (2007). Inside the Family Firm: The Role of Families in Succession Decisions and Performance. The Quarterly Journal of Economics, 122(2), 647-691. https://doi.org/10.1162/qjec.122.2.647

Carroll, A B. (1979). A Three-Dimensional Conceptual Model of Corporate Performance. The Academy of Management Review, 4(4). https://doi.org/10.2307/257850

Chen, X.-D., Wang, Y.-C., \& Huang, D.-S. (2011). Does the business decision-making of the enterprise affect accrual? ---Based on the research of the enterprise life cycle. Investment Research, (9), 12-31.

Chen, Z.-P. (2015). An Empirical Test of the Impact of my country's Small and Medium-sized Enterprises' Debt Financing on Corporate Performance. Business Economics Research, (9), 90-92.

Cheng, B., Ioannou, I., \& Serafeim, G. (2014). Corporate Social Responsibility and Access to Finance. Strategic Management Journal, 35(1). https://doi.org/10.1002/smj.2131

Du, Y., \& Liu, L.-G. (2002). An Empirical Analysis of Bond Governance Efficiency of Chinese Listed Companies. Securities Market Herald, (12), 66-69.

Fan, C., \& Ye, Z.-W. (2004). Listed company debt financing, corporate governance and corporate performance. Manager Theory and Economic Management, (10), 50-53.

Fan, J., Wong, T. J., \& Zhang, T. (2012). Founder Succession and Accounting Properties. Contemporary Accounting Research, 29(1), 283-311. https://doi.org/10.1111/j.1911-3846.2011.01099.x

Frank, Z., \& Goyal, V. (2003). Testing the Peeking Order Theory of Capital Structure. Journal of Financial Economies, 217-224. https://doi.org/10.1016/S0304-405X(02)00252-0

Hajiha, Z., \& Sarfaraz, B. (2013). Relationship between Corporate Social Responsibility and Cost of Capital in Listed Companies in Tehran Stock Exchange. World Applied Sciences Journal, 28(11).

Huo, Z.-H. (2010). Research on the governance effect of the debt financing structure of small and medium private enterprises. Industrial Technology Economy, (29), 150-152.

Jensen, M. C., \& Meckling, W. H. (1976). Theory of the Firm: Managerial Behavior, Agency Costs and Ownership Structure. SSRN Electronic Journal, 3(4). https://doi.org/10.1016/0304-405X(76)90026-X

Jenson, M. (1986). Agency Costs of Free Cash Flows, Corporate Finance and Takeovers. American Economic Review, (7), 323-329.

Liu, L., Wang, Y.-X., \& Pan, J. (2019). Economic policy uncertainty, management governance and corporate debt financing decisions. Journal of Shanxi University of Finance and Economics, 41(11), 83-97.

Liu, Y., \& Sheng, Y.-H. (2018). Research on the Impact of Manufacturing Enterprises' Debt Financing Scale on Operating Performance: Concurrently Discussing the Moderating Effect of Ownership Concentration and 
the Nature of Property Rights. Finance and Accounting Newsletter, (3).

Mathews, M. R. (1995). Social and Environmental Accounting: A Practical Demonstration of Ethical Concern?. Journal of Business Ethics, 14(8). https://doi.org/10.1007/BF00871347

Preston, L. E., \& O'Bannon, D. P. (1997). The Corporate Social Financial Performance Relationship: A Typology and Analysis. Business and Society, (4). https://doi.org/10.1177/000765039703600406

Qiu, H., \& Fan, Q.-X. (2014). An Empirical Study on the Impact of Debt Financing on the Performance of Small and Medium Listed Companies__Based on the 2010-2012 Panel Data of the Growth Enterprise Market. Enterprise Economy, (3), 94-97.

Song, Y.-P. (2015). Research on the Relationship between Debt Financing and Corporate Performance_-Taking China's Real Estate Listed Companies as an Example. Finance and Accounting Monthly, (1).

Sun, W. (2013). Research on the Corporate Governance Effect of Bank Creditor's Rights---Based on the Empirical Analysis of Small and Medium-sized Listed Companies. Times Finance, (10), 170-171.

Wang, H. (2003). Listed company debt financing, corporate governance and market value. Economic Research, (8), 28-35.

Wennberg, K., Wiklund, J., Hellerstedt, K., et al.. (2011). Implications of Intra-Family and External Ownership Transfer of Family Firms: Short-Term and Long-Term Performance Differences. Strategic Entrepreneurship Journal, (5), 352-372. https://doi.org/10.1002/sej.118

Yu, D.-Z. (2003). Capital structure, debt governance and corporate performance: an empirical analysis. China Industrial Economics, (1), 87-94.

Zhang, J.-M. (2006). The Governance Effect of Debt Financing-A New Empirical Research Design. Journal of Shanxi University of Finance and Economics, (4).

\section{Copyrights}

Copyright for this article is retained by the author(s), with first publication rights granted to the journal.

This is an open-access article distributed under the terms and conditions of the Creative Commons Attribution license (http://creativecommons.org/licenses/by/4.0/). 